\title{
SEXTING BY STUDENTS AT PALACKÝ UNIVERSITY
}

\author{
René SZOTKOWSKI*, Univerzita Palackého v Olomouci \\ Iveta KOMÁRKOVÁ, Univerzita Palackého v Olomouci
}

Přijato: 16. 8. 2017 / Akceptováno: 11. 11. 2017

Typ článku: Výzkum

DOI: $10.5507 /$ jtie.2017.028

Abstract: Sexting is a risky phenomenon that becomes a popular part of electronic communication among young people. This phenomenon did not avoid university students who consensually send and share their own intimate material. The paper describes the results of a research which focuses on the occurrence of sexting activities in a sample of students of Palacký University in Olomouc. Quantitative research was conducted by a questionnaire survey which also aimed to find out the views of selected students on this risky behavior and why are they sexting. A total of 421 students participated in the research. They filled in an electronic form of a questionnaire survey. The main result showed that $83,8 \%$ of them have sent a sexually suggestive message to someone and 63,4\% shared their nude or seminude picture/video.

Key words: sexting, student, research, risks, socially pathological phenomena.

\section{SEXTING U STUDENTŮ UNIVERZITY PALACKÉHO}

Abstrakt: Sexting je rizikový jev, který se u mladých lidí stává populární součástí elektronické komunikace. Tento fenomén se nevyhnul ani vysokoškolským studentům, kteři dobrovolně posilají a sdillejí vlastní intimni materiál. Přispěvek popisuje výsledky výzkumu, který se zabýval výskytem sextingových aktivit u výběrového souboru studentů Univerzity Palackého v Olomouci. Kvantitativní výzkum byl realizován dotazníkovým šetřením, prí kterém byly taktéž zjištovány názory vybraných studentů na toto rizikové chování a důvody, proč sexting provozují.

Do výzkumu se zapojilo celkem 421 studentů, kteři vyplnili elektronickou formu dotazníku. Z výsledkủ bylo zjištěno, že $83,8 \%$ respondenti̊ poslalo někdy jiné osobně sexuálně zaměrenou zprávu a $63,4 \%$ dotazovaných sdílelo své video nebo fotografii s intimním materiálem.

Klíčová slova: sexting, student, výzkum, rizika, sociálně patologické jevy.

*Autor pro korespondenci: rene.szotkowski@upol.cz 


\section{1 Úvod}

Mezi nebezpečné komunikační jevy, které se pomocí internetu a dalších moderních technologií staly součástí běžného života, můžeme zařadit také sexting. Ten se za posledních několik let vyvinul ve fenomén, se kterým se setkávají nejen dospělí, ale také stále mladší děti.

Sexting lze vymezit jako dobrovolné sdílení vlastních intimních materiálů, jakými jsou fotografie nebo videa a na kterých je nejčastěji právě odesílatel (Kopecký a Kožíšek 2015). Ministerstvo školství, mládeže a tělovýchovy vydalo Metodické doporučení k primární prevenci rizikového chování u dětí a mládeže (Dokument MŠMT č. j.: 21291/2010-28), v němž sexting řadí ke kyberšikaně a dalším rizikovým formám komunikace prostřednictvím multimédií. V tomto dokumentu je sexting definován jako distribuce fotografií a videí intimního charakteru bez souhlasu zobrazené osoby, tedy v tomto případě je odesílatelem jiná osoba, která tak činí proti vůli někoho jiného (MŠMT 2013-2016).

Definice sextingu je rozličná mezi dalšími autory. Nabízí se např. širší pojetí, kdy je sextingem popisováno posílání sexuálních zpráv, fotografií nebo videozáznamů převážně přes mobilní telefon, ale také prostřednictvím e-mailu, internetových diskuzí nebo jiných zařízení s připojením na internet (Kays 2011). V jiném článku je sexting ekvivalentem pro pořizování a rozšiřování nahých nebo polonahých fotografií prostřednictvím mobilních telefonů (Albury, Crawford 2012). Sborník Děti a online rizika, který vydala Linka Bezpečí, který uvádí, že tento sextingový materiál je mnohdy pořizován během milostného vztahu, přičemž existuje riziko zveřejnění fotografií nebo videa $\mathrm{z}$ různých důvodů jedním z partnerů (Karásková Ulbertová 2012).

Během výzkumu jsme vycházeli z definice Kopeckého a Koží̌ka, přikláníme se také s obsáhlejšímu vymezení od Kayse (2011). Naopak v Metodickém doporučení k primární prevenci rizikového chování u dětí a mládeže je pojetí sextingu jako aktivity konané bez souhlasu zobrazené osoby zavádějící v popisu aktéra, a proto jsme tuto definici při výzkumu neužívali.

Výzkum se tak zabýval nejen zkušenostmi se sextingem, ale také názory studentů olomoucké univerzity, kteří mohli sexting pojímat různými zpo̊soby. Proto byly jako součást výzkumné metody uvedeny definice dvou základních pojmů, podle kterých respondenti posuzovali své zkušenosti. Jako „sexy fotky/videa“ měli vybraní studenti chápat sexuálně vyzývavé, polonahé nebo nahé osobní fotografie/videa pořizená danou osobou (samostatně nebo kamarádem) - a ne ty, které lze nalézt na internetu nebo přijaté od neznámých lidí (napr. spam). Jako „sexy zprávy“ byly označeny sexuálně vyzývavé osobně napsané SMS zprávy, emaily, WhatsApp zprávy atd. - a ne ty které dostaneme od neznámého člověka (napřr. spam). Navíc bylo uvedeno, že dané zprávy se vztahují pouze k těm elektronicky napsaným (v emailu, SMS, v aplikaci WhatsApp atd.) a fotky/videa se vztahují pouze k těm elektronicky zachyceným (na mobilní telefon, smartphone nebo digitální fotoaparát či kameru).

Proč je sexting řazen mezi nebezpečné jevy lze pochopit na základě následků, které jsou s těmito aktivitami spojeny. Možné negativní následky mohou být okamžité či časově vzdálenější, mohou se týkat pouze rodiny a přátel nebo naopak zahrnují širší publikum. Bezprostřední poškození oběti často spočívá $\mathrm{v}$ ponížení při odhalení sextingu, at' už rodičem, učitelem nebo neplánovaným př́ijemcem intimního materiálu. Další formou ublížení aktérovi je nespokojenost adresáta se získanou fotografií či videem a přeposlání materiálu dalším lidem. Další úrovní může být šikana, kyberšikana, kybergrooming nebo 
obtěžování oběti př́ijemcem. Existují i extrémní případy, kdy tyto negativní důsledky skončily sebevraždou (Jolicoeur a Zedlewski 2010).

Jiný zdroj však uvádí, že většina incidentů se sexuálně zaměřeným materiálem ve výsledku neměla žádný efekt, at' už pozitivní nebo negativní. Ve více než polovině případů nezískali mladí respondenti nového prrítele nebo př́itelkyni ani to nezvýšilo jejich popularitu. Na druhé straně nedošlo k šikaně ani k traumatům, pouze přibližně čtvrtina zúčastněných osob se přiznala, že se cítí hưře. Autor přesto upozorňuje na to, jak může být sexting nebezpečný, obzvláště pokud je dítě nuceno posílat své nahé nebo polonahé fotografie pod nátlakem jiné osoby (Englander 2014).

Jedním z východisek výzkumu se stala iniciativa The National Campaign to Prevent Teen and Unplanned Pregnancy, pod kterou se uskutečnil jeden z prvních výzkumů sextingu, tzv. Sex and Tech Survey, již v roce 2008. Pětina dospívajících ve věku 13 až 19 let někdy zveřejnila či někomu poslala vlastní nahou nebo polonahou fotografii či video a 39 \% dospívajících někdy zveřejnilo nebo poslalo sexuálně vyzývavou zprávu jiné osobě. U mladých dospělých (20-26 let) byla procenta kladných odpovědí vyšší, a to $33 \%$ u obrazového sextingu a 59 \% u textové sextingu (Sex and Tech: Results from a Survey of Teens and Young Adults 2008).

V České republice věnuje sextingu pozornost Centrum prevence rizikové virtuální komunikace, které je součástí Pedagogické fakulty Univerzity Palackého v Olomouci. Jeden z posledních výzkumů, realizovaný v roce 2014 a publikovaný taktéž v časopise Komenský, který je odborným časopisem pro učitele základní školy, zjistil na vzorku 28232 respondentů, že 7,81\% dotázaných dětí ve věku 11 až 17 let zveřejnilo vlastní sexuálně zaměřenou fotografii nebo video na internetu. V 12,14 \% prŕípadů byl obdobný materiál poslán jiné osobě. Jako riskantní vnímalo sexting 77,50 \% zúčastněných dětí (Kopecký, Szotkowski, Gibadulin 2014).

Na univerzitní studenty byl taktéž zacílen výzkum z roku 2013, který se zabýval rizikovým chováním v prostředí internetu u studentů Pedagogické fakulty Univerzity Palackého v Olomouci. Z 386 zapojených studentů byla většina ve věkovém rozmezí 20 až 25 let, přičemž 12,42 \% z nich zveřejnilo vlastní sexuálně vyzývavou fotografii nebo video na internetu. Tento materiál poslalo další osobě celkem $23,28 \%$ respondentů. Sledujeme tedy nárůst sextingových aktivit oproti dospívajícím dětem, které studují na základních a středních školách. Lze konstatovat, že s věkem mají mladí lidé více zkušeností se sextingem. Výsledky výzkumu však poukázaly na to, že v České republice není tento fenomén natolik rozšiŕený jako $\mathrm{v}$ zahraničí, kde se výskyt sextingu u adolescentů pohybuje mezi 20 až $70 \%$ (Kopecký 2013).

Tento výzkum byl zaměřen na věkovou skupinu 17 až 30 let. Období adolescence neboli období pozdního dětství je ohraničeno 12/13 až 19 lety věku a období od 20 do 35 let lze označit jako mladou dospělost. Dalším termínem, který můžeme spojovat s vysokoškolskými studenty, je nezralá dospělost. V období adolescence jsou na dospívajícího člověka kladeny sociální požadavky, které jej mají připravit na sociálně zodpovědné chování. Kromě stresových situací plynoucích z těchto požadavků se mezi dospávajícími objevuje také provokativní chování a testují se reakce dospělých. Kvůli snaze o dosažení nezávislosti může být vztah s rodiči napjatý a kontrola aktivit dítěte se stává citlivým tématem. Skrývání informací a konflikty s rodiči v důsledku brání odhalení delikventního chování. Dospívajícímu navíc chybí životní zkušenosti, které by mohly pozitivně ovlivnit jejich chování, přičemž od rodičů tyto názory nepřijímají. V období 
dospívání se formuje vztah k okolnímu světu a také osobní identita neboli pocit vlastní totožnosti. Potřeba někam patřit a sociální naivita mladých lidí může být zneužita proti nim, pokud si nedávají dostatečný pozor ve virtuálním světě. Na internetu mohou adolescenti jednoduše experimentovat s identitou, avšak kvůli jejich touze po seznamování se mohou stát obětmi napřr. kyberšikany, vydírání, vyhrožování apod. (Thorová 2015). Proto považujeme vysokoškolské studenty za rizikovou skupinu, která se sextingu nevyhýbá, ale naopak jej aktivně vyhledává.

\section{Cíl a metodologie výzkumu}

Výzkum byl realizován koncem roku 2016 a jeho hlavním cílem bylo zjistit výskyt sextingu u studentů Univerzity Palackého v Olomouci. Dílčími cíli bylo zjistit názory vybraných studentů na poměr výskytu aktivit spojených se sextingem $\mathrm{v}$ jejich věkové skupině, dále zjistit, jak vysokoškolští studenti vnímají samotné sextingové aktivity a osoby provozující sexting, dále zjistit u studentů, kteří někdy provozovali sexting, které osobě a z jakých důvodů poslali sexuálně laděný materiál, př́í. od koho takový materiál obdrželi a jak se v dané situaci cítili apod.

\subsection{Použité výzkumné metody}

Výzkum byl orientován kvantitativně a pro sběr dat byl vybrán dotazník. Pro tvorbu dotazníku byl využit standardizovaný nástroj z výzkumu The National Campaign to Prevent Teen and Unplanned Pregnancy z roku 2008, jehož výsledky jsme nastínili v úvodu. Původní výzkumný nástroj obsahoval 25 položek. Některé, nehodící se položky jsme vyřadili, jiné položky byly sohledem na zkoumaný vzorek a prostředí dílčím způsobem upraveny. Výsledný dotazník obsahoval 22 položek, z toho dvě položky byly dichotomické, 12 polynomických výčtových (8 polouzavřených), dále čtyři polynomické výběrové a zbylé čtyři položky škálové. Převážná část položek zůstala identická s položkami zmíněné studie z roku 2008. Vynechána byla např. položka, ve které měli respondenti vyjádřit na škále svůj souhlas či nesouhlas s vybranými výroky. V otázce o využívaných technologiích byly modifikovány odpovědi vzhledem $\mathrm{k}$ současným trendům a novým komunikačním technologiím. Doplněny byly otázky pro studenty univerzity, kdy respondenti vybírali úroveň studia na vysoké škole a studovanou fakultu.

Další fáze dílčích modifikací výzkumného nástroje proběhla za pomoci oslovení osob z řad odborníků i respondentů, kteř́ se zaměřili na obsahovou i jazykovou stránku dotazníku a pomohli s jeho dodatečnou úpravou. Během pilotní studie následně došlo k závěrečné úpravě některých položek, např. doplnění možnosti, že respondent nezvolí žádnou z uvedených odpovědí, nebo odebrání či zkombinování možností se stejným či podobným významem. Konečná verze dotazníku byla následně převedena do elektronické podoby pomocí Google formuláře a hromadně distribuována respondentům z řad studentů Univerzity Palackého v Olomouci.

Vzhledem k minimálním úpravám a zásahům do již existujícího standardizovaného nástroje byla do značné míry zaručena validita a reliabilita výsledného dotazníku. 


\subsection{Popis výzkumného vzorku}

Výběr respondentů do výzkumného vzorku probíhal formou záměrného výběru, konkrétně výběru anketního (Chráska 2016), kdy studenti sami rozhodovali, zda se výzkumu zúčastní a nabídnutý dotazník vyplní.

Do výzkumu se zapojilo celkem 421 respondentů. $Z$ tohoto počtu jsme vyloučili celkem 8 studentů, kteří po úvodní části dotazníku odmítli pokračovat, protože jim nebylo př́jemné sdílet jejich názory na problematiku sextingu. Po eliminaci výše uvedených 8 studentů jsme při následném zpracování a analýze dat pracovali s výzkumným vzorkem 413 studentů, kteří v roce 2016 navštěvovali Univerzitu Palackého v Olomouci. Mezi dotazovanými osobami převažovaly ženy, které tvořily 75,8 \% výzkumného vzorku. Získali jsme výzkumná data od 313 studentek oproti 100 studentům mužského pohlaví, kteří tvořili zbylých $24,2 \%$.

Věkové rozložení studentů, kteří se zapojili do výzkumu, bylo stanoveno na 17 až 30 let. Nejpočetnější kategorií byli studenti od 20 do 26 let, kteří tvořili $93,4 \%$ všech respondentů ( $60 \%$ ve věku 20 až 22 let a $33,4 \%$ ve věku 23 až 26 let).

\section{Průběh a výsledky výzkumu}

Vzhledem k rozsahu provedeného výzkumu prezentujeme $\mathrm{v}$ př́spěvku pouze dílčí části deskriptivních výsledků. V úvodní části dotazníku jsme zjišt'ovali, jaké komunikační technologie a služby používají současní studenti olomoucké univerzity. S osobním počítačem manipuluje $96,9 \%$ respondentů, zatímco smartphone používá pro komunikaci 64,4 \% dotazovaných osob. Mezi komunikačními službami jsou neoblíbenější Facebook $(99,8 \%)$, YouTube $(95,0 \%)$ a Skype $(71,0 \%)$. Tyto platformy jsou snadno dostupné a při provozování sextingu mohou být velmi nápomocné.

Podle zúčastněných studentů je velmi častou aktivitou mezi vrstevníky posílání zpráv s vlastním intimním obsahem jiné osobě, což si myslí $84,7 \%$ z nich. O něco méně, a to 64,2 \% respondentů, považuje za obvyklé také posílání vlastních sexuálně zaměřených fotografií nebo videí.

V následující tabulce č. 1 je zaznamenáno, kolik ze 413 vybraných studentů Univerzity Palackého považuje sextingové chování mezi lidmi ze stejné věkové skupiny za docela obvyklé či velmi obvyklé.

\begin{tabular}{|l|c|c|c|c|}
\hline & \multicolumn{2}{|c|}{ Docela obvyklé } & \multicolumn{2}{c|}{ Velmi obvyklé } \\
\cline { 2 - 5 } & Četnost & Rel. četnost & Četnost & Rel. četnost \\
\hline Posílání sexy zpráv jiné osobě & 211 & 51,1 & 139 & 33,7 \\
\hline $\begin{array}{l}\text { Sdílení sexy zpráv s jinými } \\
\text { osobami než s těmi, pro které } \\
\text { byly určeny }\end{array}$ & 82 & 19,9 & 12 & 2,9 \\
\hline $\begin{array}{l}\text { Posílání vlastních sexy } \\
\text { fotek/videí jiné osobě }\end{array}$ & 206 & 49,9 & 59 & 13,6 \\
\hline $\begin{array}{l}\text { Sdílení sexy fotek/videí s } \\
\text { jinými osobami než s těmi, } \\
\text { pro které byly určeny }\end{array}$ & 75 & 18,2 & 18 & 4,4 \\
\hline
\end{tabular}

Tab. č. 1: Jak obvyklé jsou podle studentů UP aktivity spojené se sextingem v jejich věkové skupině 
Co se týče pohlaví, podle 58,8 \% studentů je posílání sexuálně vyzývavého materiálu více obvyklé u žen než u mužů, u zveřejňování tohoto materiálu online má stejný názor dokonce $69,7 \%$ respondenti̊. Naproti tomu textový sexting je podle 52,3\% dotázaných osob stejně obvyklý u mužů i u žen.

Nejčastějším důvodem žen k provozování sextingu je podle respondentů snaha upoutat na sebe pozornost, s čímž souhlasí 85,7 \% studentů. Více než tři čtvrtiny respondentů vidí motiv také v získání pozitivní odezvy a posílání tohoto materiálu jako „sexy“ dárku pro přítele. U důvodů mužů se dvě třetiny studentů shodly, že muži na sebe chtějí upoutat pozornost, touží získat pozitivní reakci a chtějí být tímto způsobem zábavní nebo takto flirtují.

Za nebezpečný je sexting považován u 77,0 \% odpovědí. Přesto jej 72,4 \% respondenti̊ označuje za flirtující a 63,2 \% jako vzrušující. Osobu, která sexting provozuje, vnímá 77,7 \% studentů jako flirtující, avšak nesouhlasí s tím, že by tato osoba byla cool, což si myslí pouze 5,6\% dotázaných osob.

Další dvě položky jsou vyjádřeny v následujících dvou tabulkách č. 2 a 3, které znázorňují vlastní zkušenosti vybraných 413 vysokoškolských studentů se sextingem. Z dotázaných studentů má 83,8 \% zkušenost s posíláním sextingové zprávy, zatímco takovou zprávu obdrželo dokonce $85,7 \%$ respondentů. U obrazového sextingu jsou zjištěné hodnoty nižší, kdy 63,4 \% studentů někdy odeslalo vlastní sexuálně zaměřenou fotografii nebo video a 71,4 \% dotázaných osob někdy takový materiál obdrželo.

\begin{tabular}{|l|c|c|}
\hline & Četnost & Rel. četnost \\
\hline Poslání zprávy & 346 & 83,8 \\
\hline $\begin{array}{l}\text { Zveřejnění zprávy na online } \\
\text { profilu jiné osoby }\end{array}$ & 8 & 1,9 \\
\hline Obdržení zprávy od někoho & 354 & 85,7 \\
\hline $\begin{array}{l}\text { Sdílení zprávy s jinými osobami } \\
\text { než s těmi, pro které byla určena }\end{array}$ & 72 & 17,4 \\
\hline $\begin{array}{l}\text { Jiná osoba sdílela původně } \\
\text { soukromou zprávu }\end{array}$ & 148 & 35,8 \\
\hline Žádná aktivita z uvedených & 28 & 6,8 \\
\hline
\end{tabular}

Tab. č. 2: Provozování sextingu s textovým materiálem u studenti̊ UP 


\begin{tabular}{|l|c|c|}
\hline & Četnost & Rel. četnost \\
\hline Poslání fotografie nebo videa & 262 & 63,4 \\
\hline $\begin{array}{l}\text { Zveřejnění fotografie nebo videa } \\
\text { na online profilu jiné osoby }\end{array}$ & 8 & 1,9 \\
\hline $\begin{array}{l}\text { Obdržení fotografie nebo videa } \\
\text { od někoho }\end{array}$ & 295 & 71,4 \\
\hline $\begin{array}{l}\text { Sdílení fotografie nebo videa s } \\
\text { jinými osobami než s těmi, pro } \\
\text { které byla určena }\end{array}$ & 45 & 10,9 \\
\hline $\begin{array}{l}\text { Jiná osoba sdílela původně } \\
\text { soukromou fotografii nebo video }\end{array}$ & 130 & 31,5 \\
\hline Žádná aktivita z uvedených & 71 & 17,2 \\
\hline
\end{tabular}

Tab. č. 3: Provozování sextingu s obrazovým materiálem u studenti̊ UP

Pokud se zaměříme na př́jemce sextingového materiálu, v 74,8 \% případů je to přítel nebo přítelkyně a u 37,5 \% se jednalo o osobu, se kterou zúčastněné osoby randily nebo si s ní užívaly.

Odesílatelem byl přítel nebo přítelkyně 70,2 \% respondenti̊, zatímco 40,7 \% studentů obdrželo sexuálně vyzývavý materiál od někoho, s kým si užívali nebo randili.

Skutečným důvodem k provozování sextingu je především darování své fotografie či videa, což uvedlo 54,0 \% studenti̊. Druhým nejobvyklejším motivem je zábava či flirt $(44,6 \%)$, naopak nejméně častými důvody jsou snaha upoutat pozornost $(9,9 \%)$ a donucení, což přiznalo pouze $7,3 \%$ respondentů.

Nejčastěji byli studenti při obdržení „,sexy“ materiálu od jiné osoby vzrušeni $(69,7 \%)$, překvapeni $(57,1 \%)$ a pobaveni $(55,0 \%)$. Strach uvedlo $6,8 \%$ respondentů, zklamaných bylo $4,1 \%$.

Většina studentů cizí intimní materiál s nikým nesdílí, jak uvedlo 63,2 \% studentů. Pokud ano, jedná se o osobu blízkou nebo přátele, což přiznalo $31,7 \%$ respondenti̊.

Poslední položka, která se týkala tohoto fenoménu, zjištovala obavy studentů z provozování sextingu. $\mathrm{V}$ tabulce č. 4 vidíme, že nejběžnější obavou je následná lítost $(84,3 \%)$, dále strach z potenciální ostudy $(69,5 \%)$ a taktéž ublížení vztahu nebo šanci nějaký mít, což uvedlo 50,6 \% studentů. Někteří studenti vybrali možnost ,Jiné“, přičemž sami napsali jejich možné obavy z provozování sextingu. Převážná většina z nich uváděla strach ze zneužití a publikace na internetu. Další alternativní odpovědí bylo např. tvrzení, že ,lidé by si mysleli, že jsem zoufalec“. 


\begin{tabular}{|l|c|c|l|c|c|}
\hline & Četnost & $\begin{array}{c}\text { Rel. } \\
\text { četnost }\end{array}$ & Četnost & $\begin{array}{c}\text { Rel. } \\
\text { četnost }\end{array}$ \\
\hline $\begin{array}{l}\text { Později by toho } \\
\text { litoval/a }\end{array}$ & 348 & 84,3 & $\begin{array}{l}\text { Problém ve } \\
\text { škole }\end{array}$ & 92 & 22,3 \\
\hline Potenciální ostuda & 287 & 69,5 & $\begin{array}{l}\text { Problém se } \\
\text { zákonem }\end{array}$ & 76 & 18,4 \\
\hline $\begin{array}{l}\text { Ublížení vztahu nebo } \\
\text { šanci na vztah }\end{array}$ & 209 & 50,6 & $\begin{array}{l}\text { Zklamání učitele } \\
\text { nebo trenéra }\end{array}$ & 27 & 6,5 \\
\hline $\begin{array}{l}\text { Uvidí to } \\
\text { zaměstnavatel }\end{array}$ & 178 & 43,1 & Jiné & 22 & 5,3 \\
\hline $\begin{array}{l}\text { Zklamání rodiny nebo } \\
\text { přátel }\end{array}$ & 166 & 40,2 & $\begin{array}{l}\text { Žádný z těchto } \\
\text { důvodú / Neví }\end{array}$ & 20 & 4,8 \\
\hline Údajná promiskuita & 107 & 25,9 & $\begin{array}{l}\text { Má špatnou } \\
\text { zkušenost }\end{array}$ & 13 & 3,1 \\
\hline
\end{tabular}

Tab. č. 4: Obavy studentĩ UP z provozování sextingu

\section{Diskuze}

Z provedeného výzkumu vyplynulo, že studenti Univerzity Palackého v Olomouci pro vzájemnou komunikaci se svými vrstevníky nejčastěji používají notebook a smartphone, tedy prrístroje, které ve většině př́padů nejsou sdíleny s další osobou. $Z$ toho by mohl vyplývat pocit bezpečí a soukromí, který může majitel smartphonu vnímat při pořizování vlastního intimního materiálu.

Mezi komunikačními službami a aplikacemi je oblíbený Facebook, YouTube a Skype. Poslední zmíněná služba je často doprovázena živým vysíláním obrazu přes webkameru, což může vést $\mathrm{k}$ sextingu $\mathrm{v}$ př́mém přenosu.

Pokud podle následujícího grafu porovnáme zjištěnou realitu provozování sextingových aktivit sodhadem, jak jsou tyto činnosti obvyklé mezi vrstevníky respondentů, procentuální výsledky jsou si velmi podobné. 


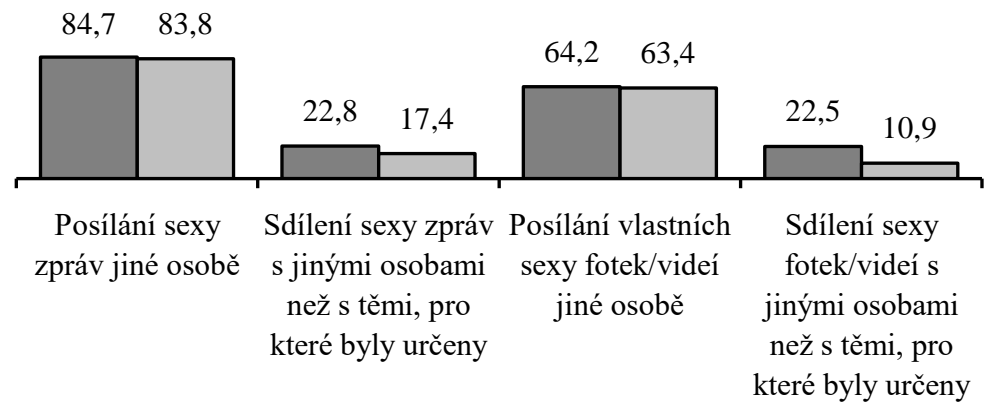

Předpoklad (v \%) $\square$ Realita (v \%)

Graf č. 1: Jak obvyklé jsou podle vybraných studentů UP aktivity spojené se sextingem v jejich věkové skupině a jaké aktivity skutečně provozovali

Rozdíl mezi předpokladem a realitou posílání textového i obrazového sextingu u vysokoškolských student je v obou případech menší než dvě procenta, což naznačuje, že studenti jsou si vědomi výskytu těchto aktivit a o tomto fenoménu nemají zkreslené představy.

To však neplatí u údajných a skutečných důvodů k sextingu, kdy si více než čtyři pětiny respondentů myslí, že důvodem je upoutání pozornosti na sebe, přičemž ve skutečnosti jej jako reálný důvod označila pouze necelá desetina studentů. Ukazuje se zde rozdílné posuzování mezi vlastními a cizími motivy, které se zkreslují negativně. Většina dotázaných osob sice považuje sexting za nebezpečný, ale méně než pětina z nich jej charakterizuje jako nemorální, čímž si tedy nespojují sexting se sociálně patologickými jevy a chybí jim vnitřní zábrany k jeho provozování.

Dále bylo také zjištěno, že čtyři pětiny studentů mají zkušenost s posíláním sextingové zprávy, zatímco u obrazového sextingu je jich o pětinu méně. Textový sexting lze považovat za jednodušší, méně závažný a méně nebezpečný, což může vést $\mathrm{k}$ tak vysokým procentům výskytu u studentů univerzity.

Více než polovina respondentů provozovala sexting za účelem darování své fotografie či videa. Druhým nejčastějším motivem byla zábava či flirt, a to u 44,6 \% dotázaných studentů. Tyto důvody potvrzují definici Kopeckého a Kožíška, že se jedná o dobrovolné sdílení vlastních intimních materiálů. Na druhou stranu 7,3 \% zúčastněných osob uvedlo, že byli ksextingu donuceni pod nátlakem. Pojetí provozování sextingu na principu dobrovolnosti je tedy $\mathrm{v}$ tomto prrípadě nepřesné.

Přítel či přítelkyně byli nejčastějšími př́iemci $(74,8 \%)$ i odesílateli $(70,2 \%)$ intimního materiálu. Osoba, se kterou respondenti randili nebo si s ní užívali, tento materiál obdržela od $37,5 \%$ studentů. 40,7 \% dotázaných od takové osoby obdrželo sexuálně vyzývavý materiál. Tato procenta podporují definici Karáskové Ulbertové ze Sborníku Děti a online rizika, kde je uvedeno, že sextingový materiál je mnohdy pořizován během milostného vztahu. 
Při srovnání získaných dat s výzkumem Sex and Tech Survey z roku 2008 (Sex and Tech: Results from a Survey of Teens and Young Adults 2008), kdy se jednalo o stejnou věkovou kategorii respondentů, můžeme konstatovat, že mladí Američané nebrali sexting za tolik nebezpečný jako spíše nemorální, což je opakem našeho zjištění. Pozornost je dnes více zaměřena na rizika sextingu než na morální podstatu věci. S tím souvisí také fakt, že u olomouckých studentů se označení osoby provozující sexting za promiskuitní snížilo o tři desítky procent. Sexting se v této době již tolik neodsuzuje, spolu s osobou provozující sexting je vnímán méně negativně než před 8 lety v USA a mezi mladými je považován spíše za zábavu a způsob povyražení.

Dokládá to také zjištění, že u posílání textového sextingu došlo vůči výše zmíněnému výzkumu ke zvýšení o 24 \%. Obdržení „sexy“ zprávy je častější o 21 \%, posílání obrazového sextingu dosáhlo nárůstu dokonce o $29 \%$ a u obdržení sexuálně vyzývavých fotografií nebo videí je patrné navýšení o $24 \%$.

Další srovnání jste provedli s výzkumem, který proběhl na přelomu let 2012 a 2013 na Pedagogické fakultě Univerzity Palackého v Olomouci (Kopecký 2013). Naše výsledky ukazují o 37,4 \% častější zkušenost s obrazovým sextingem, než jakou zjistil výzkum na jedné z osmi fakult, které jsme zahrnuli do výběrového souboru. Je tedy možné, že během posledních tří let se sexting za pomoci modernějších komunikačních technologií, služeb a aplikací stal běžnou praktikou studentů vysoké školy.

Tyto výsledky a závěry výzkumu mohou být aplikovány na další vysoké školy v České republice, avšak nabízí se otázka, nakolik je zkušenost se sextingem ovlivněna množstvím studentů, nabízenými obory studia, dostupnými technologiemi, kolektivem či lokalitou jedné univerzity v České republice. Další limity studie mohou být spatřovány v samotném nástroji sběru dat a jednotlivých položkách. Sběr dat probíhal elektronicky, což může mít za následek také převahu žen, která však není ve specifickém prostředí univerzity ojedinělá.

Z výsledků studie je patrný výrazný nárůst provozování sextingu mezi mladými lidmi, a proto by se další výzkum mohl zaměřit na zjištění doby, kdy u dětí a dospívajících dochází k první zkušenosti se sextingem, dále jaké př́íčiny vedou k tomuto chování, zda se setkali s negativními následky a jestli je možné se proti tomu preventivně bránit. Také by nás mohlo zajímat, zda se jednalo pouze o ojedinělou zkušenost, př́ípadně jak často sexting provozují.

Smyslem realizace výzkumu bylo poukázat na zvyšující se trend provozování sextingových aktivit mezi mladými lidmi. Zdánlivě neškodné chování, které je v této době navíc mezi adolescenty považováno za běžné, však skrývá rizika, která mohou vyústit až v ublížení na zdraví a smrt. Kromě dalších studií by měli zasáhnout také rodiče a učitelé, kteří by s dětmi vedli dialog o nebezpečných komunikačních jevech v internetovém prostředí.

\section{Závěr}

Na vzorku 413 respondentů z řad studentů Univerzity Palackého v Olomouci bylo zjištěno, že většina z nich někdy poslala sexuálně zaměřenou zprávu, fotografii nebo video jiné osobě. I když jsou si studenti vědomi možných rizik sextingu, největší obavu mají z následné lítosti a potenciální ostudy. Sexting není respondenty považován za nemorální a osoba provozující sexting nejčastěji působí velmi sebevědomě. Více než třetina zúčastněných však vidí tuto osobu jako hloupou a nezralou. Podle odhadu studentů je 
jedním z nejčastějších důvodů k provozování sextingu upoutání pozornosti, přičemž tento záměr přiznala pouze necelá desetina $\mathrm{z}$ nich. Více než polovina vybraných studentů vyzkoušela sexting za účelem darování vlastního intimního materiálu př́teli nebo prítelkyni. Nejméně častým důvodem bylo donucení pod nátlakem. Můžeme tudíž konstatovat, že sexting je u studentů Univerzity Palackého převážně dobrovolnou aktivitou.

\section{Literatura}

Albury, K. a Crawford K. (2012). Sexting, consent and young people's ethics: Beyond Megan's story. Continuum: Journal of Media \& Cultural Studies. Roč. 26, č. 3, s. 463473. ISSN 1030-4312.

Englander, E. (2014). Stop demonizing teen sexting. In most cases, it's completely harmless. In: The Washington Post [online]. Dostupné z: www.washingtonpost.com/posteverything/wp/2014/11/07/stop-demonizing-teen-sextinginmost- cases-its-completely-harmless/

Chráska, M. (2016). Metody pedagogického výzkumu: základy kvantitativního výzkumu. Vyd. 1. Praha: Grada. 256 s. ISBN 978-80-247-5326-3.

Jolicoeur, M. a Zedlewski E. (2010). Much Ado About Sexting [online]. USA: National Institute of Justice. Dostupné z: https://www.ncjrs.gov/pdffiles1/nij/230795.pdf

Karásková Ulbertová, Z. (2012). Rodič, vychovatel a dítě na internetu. In: Děti a online rizika, sbornik studii. Praha: Sdružení Linka bezpečí. ISBN 978-80-904920-3-5.

Kays, T. (2011). What is sexting?. In: Examiner.com [online]. Dostupné z: http://www.examiner.com/article/what-is-sexting-1

Kopecký, K. (2013). Rizikové chování studentů Pedagogické fakulty Univerzity Palackého $v$ Olomouci v prostředí internetu. 1. vyd. Olomouc: Univerzita Palackého v Olomouci. ISBN 978-80-244-3858-0.

Kopecký, K., Szotkowski R. a Gibadulin D. (2014). Kyberšikana, sexting a rizikové seznamování českých dětí v prostředí internetu. Komenský: časopis pro učitele základní školy. Roč. 139, č. 2, s. 10-16. ISSN 0323-0449.

Kopecký, K. a Kožíšek M. (2015). Fenomén sexting v teorii a praxi. Skauting: dvouměsičník pro skautskou výchovu [online]. Roč. 53, č. 1, s. 4-7. ISSN 1210-9827. Dostupné $\quad \mathrm{z}: \quad \mathrm{http} / /$ krizovatka.skaut.cz/dokumenty/category/623776?download=769:skauting-unor-2015

MŠMT. (2013-2016). Metodické doporučení k primární prevenci rizikového chovaní u dětí, žáků a studentů ve školách a školských zařízeních. In: MŠMT: Ministerstvo školství, mládeže a tělovýchovy [online]. Dostupné z: http://www.msmt.cz/vzdelavani/socialniprogramy/metodicke-dokumenty-doporuceni-apokyny

Sex and Tech: Results from a Survey of Teens and Young Adults. (2008) In: The National Campaign to Prevent Teen and Unplanned Pregnancy [online]. Dostupné z: http://thenationalcampaign.org/sites/default/files/resource-

primarydownload/sex_and_tech_summary.pdf

Thorová, K. (2015). Vývojová psychologie: proměny lidské psychiky od početí po smrt. Vyd. 1. Praha: Portál. ISBN 978-80-262-0714-6. 